\title{
Canine Mammary Adenoma
}

National Cancer Institute

\section{Source}

National Cancer Institute. Canine Mammary Adenoma. NCI Thesaurus. Code C147073.

An adenoma arising from the mammary gland of a dog. 